\title{
Execution efficiency research of different ways of serves in the beach volleyball men's teams competitive activity
}

\author{
Melnyk A.Yu. ${ }^{1}$, Strelnykova Y.Y. ${ }^{2}$
}

${ }^{1}$ Kharkiv state academy of physical culture

${ }^{2}$ H.S. Skovoroda Kharkiv national pedagogical university

\section{DOI: https://doi.org/10.34142/HSR.2019.05.02.07}

\section{Abstract}

Purpose: to develop the technique for assessment of quantitative indicators of execution efficiency of serves in competitions of beach volleyball league in Kharkiv among men's amateur teams.

Material and methods: the analysis of statistical data, which are obtained as a result the pedagogical observations of power jump serves and aimed serves in 25 games of these competitions, is carried out (with total number of serves 2055). The following methods were used: analysis of scientific-methodical literature; pedagogical observation, methods of mathematical statistics.

Results: calculated: distributions of power jump serves and aimed serves according to a certain four-point rating scale; quantitative indicators of execution efficiency of serves which are generalized by results of the analysis of the relevant statistical data. The results of the corresponding calculations showed that players tried not to execute serves in the $4^{\text {th }}, 5^{\text {th }}$ and $6^{\text {th }}$ conditional zones because the rival's players are there who after serve receiving in most cases precisely addressed a ball to the partner for the organization of attack in reply. Power jump serves weren't also given to 1, 2 and 3 zones, and their greatest number was sent to the 8 and 9 zones. The direction of aimed serve generally concentrated in the $8^{\text {th }}$ and also the $2^{\text {nd }}$ zones of the playground. The assessment of indicators of serve efficiency, which were directed to different conditional zones of the court, is carried-out.

Conclusions: the technique for carrying out the analysis of statistical data concerning execution of different ways of serves in beach volleyball competitions and assessment of the corresponding quantitative indicators of their execution efficiency is generalized. The results can be used in solving the problem of increase in execution efficiency of serves in the course of training and competitive activities of beach volleyball teams.

Keywords: zone, distribution, indicator, effectiveness, assessment.

\section{Анотація}

Мельник А.Ю., Стрельнікова Є.Я. Дослідження ефективності виконання різних способів подач у змагальній діяльності чоловічих команд з пляжного волейболу

Мета: узагальнити методику для оцінки кількісних показників ефективності виконання подачі в змаганнях пляжної волейбольної ліги м. Харкова серед чоловічих аматорських команд.

Матеріал та методи: проведено аналіз статистичних даних, які одержані в результаті педагогічних спостережень за виконанням силових подач у стрибку та націлених подач в 25 іграх (з загальною кількістю подач 2055) даних змагань. Використовувались наступні методи: аналіз наукової-методичної літератури; педагогічне спостереження, методи математичної статистики.

Результати: розраховані: розподіли силових подач у стрибку та націлених подач відповідно визначеної чотирибальної шкали оцінок; кількісні показники ефективності виконання цих подач, які узагальнені по результатам аналізу відповідних статистичних даних. Результати відповідних розрахунків показали, що гравці намагалися не подавати, в 4, 5 та 6 умовні зони, оскільки там знаходяться гравці суперника, які після прийому подачі у більшості випадків точно адресували м'яч партнеру для організації атаки у відповідь. Силову подачу у стрибку також не подавали у 1, 2 та 3 зони, а найбільшу їх кількість направляли в 8 та 9 зони. Напрямок націлених подач в основному зосереджувався в 8, а також 2 зону ігрового майданчика. Проведена також оцінка показників ефективності подач, які були спрямовані в різні зони ігрового майданчика.

Висновки: узагальнена методика для проведення аналізу статистичних даних стосовно виконання різних способів подачі в змаганнях з пляжного волейболу та оцінки відповідних кількісних показників ефективності їх виконання. Результати можуть бути використані у вирішенні проблеми підвищення ефективності виконання подачі в процесі тренувальної та змагальної діяльності волейбольних команд з пляжного волейболу.

Ключові слова: зона, розподіл, показник, результативність, оцінка.

\section{Аннотация}

Мельник А.Ю., Стрельникова Е.Я. Исследование эффективности выполнения различных способов подач в соревновательной деятельности мужских команд по пляжному волейболу.

Цель: обобщить методику для оценки количественных показателей эффективности выполнения подачи в соревнованиях пляжной волейбольной лиги г. Харькова среди мужских любительских команд.

Материал и методы: проведен анализ статистических данных, полученных в результате педагогических наблюдений за выполнением силовых подач в прыжке и нацеленных подач в 25 играх (с общим количеством подач 2055) данных соревнований. Использовались следующие методы: анализ научной методической литературы; педагогическое наблюдение, методы математической статистики.

Результаты: рассчитаны: распределения силовых подач в прыжке и нацеленных подач в соответствии с определенной четырехбалльной шкалой оценок; количественные показатели эффективности выполнения этих подач, которые обобщены по результатам анализа соответствующих статистических данных. Результаты соответствующих расчетов показали, что игроки старались не подавать, в 4, 5 и 6 условные зоны, поскольку там находятся игроки соперника, которые в большинстве случаев после приема подачи точно адресовали мяч партнеру для организации атаки в ответ. Силовую подачу в прыжке также не подавали в 1, 2 и 3 зоны, а наибольшее их количество направляли в 8 и 9 зоны. Направление нацеленных подач в основном сосредоточен в 8, а также 2 зону игровой площадки. Также проведена оценка показателей эффективности подач, которые были направлены в различные зоны игровой площадки.

Выводы: обобщена методика для проведения анализа статистических данных по выполнению различных способов подачи в соревнованиях по пляжному волейболу и оценки соответствующих количественных показателей эффективности их выполнения. Результаты могут быть использованы в решении проблемы повышения эффективности выполнения подачи в процессе тренировочной и соревновательной деятельности волейбольных команд по пляжному волейболу.

Ключевые слова: зона, распределение, показатель, результативность, оценка. 


\section{Introduction}

The development of beach volleyball in Ukraine, as well as in the international arena, the successful debut at the Atlanta Olympic Games and participation in further Olympic forums, the expansion of the network of international and national competitions attracts the attention of organizers, coaches, athletes and spectators $[1,2]$.

Success in the competitive activities of beach volleyball teams is determined by various factors that require close attention. The decisive factor for winning games in both men's and women's teams is submission. [3] This is one of the main techniques by which the ball is introduced into the game without affecting its teammates and opponents in order to win a point immediately after its execution or to complicate its reception in order to disrupt the organization of the appropriate attack [2 , 4-6].

In this case, volleyball players, as a rule, have to overcome difficulties that prevent them from completing the pitch qualitatively. They are related to external weather conditions, especially strong wind, rain, bright sun, high air temperature, hot sand $[2,3,7]$.

Important in beach volleyball, as in classical volleyball, is the ability of players to perform 2-3 types of innings powerfully and accurately and effectively apply them depending on the playing situation. Considering that the size of the playground (16x8 $\mathrm{m})$ in beach volleyball is almost the same as in the classic $(18 \times 9 \mathrm{~m})$, and there are only two players, it is obvious that each player in the first case is much more responsible for the success of the submission . On the complexity of the submission depends largely on the quality of receiving the ball by the opponent, which, in turn, affects the efficiency of his transfer to the attacker and, ultimately, creates the prerequisites for winning a point. Given that in classical volleyball, up to 5 players can take part in receiving the ball, it is much more difficult for a team of two players (one blocking and one defender) to organize a high quality reception in the beach volleyball. This also applies to game actions after successful receiving of the ball from the pitch, which are related to the subsequent transfer of his partner for the execution of the striker in response, the result of which depends largely on the role of the player receiving the transfer $[3,8,9]$.

Beach volleyball is most commonly used in the form of serves such as: jumping (it can be power or top straight), planning and candlelight. Currently, two-thirds of innings are done in the jump. The serves in the jump alternate with the goals (mostly in the last meter of the playground). Increasingly, scheduling serves are used in the jump $[2,3]$.
It should be noted that in the current scientific and methodological literature, the studies that are related to the problem of increasing the efficiency of performing different ways of giving in beach volleyball, is not enough. When analyzing statistics on the performance of the submission in the competitive activity of teams widely used method of scoring the level of its performance, based on a fourpoint scale, which includes from 2 to 5 points $[2,10$ 12]. This system, in our opinion, allows only very superficial description of the quality of the filing. It is clear that in the framework of this methodology it is not possible to obtain detailed information on the quantitative characteristics of the efficiency of filing by individual players and teams, depending on various factors. Therefore, from a practical point of view, further study and improvement of different methods of evaluating the quantitative indicators of the effectiveness of different ways of submission in competitive activities is important for the coaches of the team and the professionals of beach volleyball.

The purpose of the work: to summarize the methodology for evaluating quantitative performance indicators of submission in Kharkiv beach volleyball competitions among men's amateur teams.

\section{Material and methods}

The paper analyzes the statistics obtained during pedagogical observations on the performance of submissions in 25 games of Kharkiv beach volleyball league among men's amateur teams [3]. The following methods were used: analysis of scientific and methodological literature; pedagogical observations, methods of mathematical statistics.

\section{Results}

Techno-tactical improvement of performance by volleyball players of different types of innings, improvement of their efficiency and quality is one of the main reserves for improving the effectiveness of competitive activity in volleyball. At the present stage of its development, there is an urgent need for a more detailed analysis of the efficiency of filing, which will allow coaches to use the results obtained and promptly make adjustments both in the training process and in the competitive activities of teams [4].

The analysis of literary sources devoted to various aspects of classical volleyball showed that many authors [13-18] repeatedly made attempts to create methods for evaluating the technical and tactical actions of volleyball players in competitive 
activities. As for beach volleyball, like in the case of classical volleyball, the ball scoring technique is often used to assess the level of performance. This technique allows to evaluate to a considerable extent only the qualitative component of the performance of the filing: excellent is rated at 5 points, good - 4, satisfactory - 3, unsatisfactory - $2[2,12]$. Such a simplified system of assessments allows for a significant risk of subjectivity in determining the appropriate assessment, does not contain quantitative characteristics of performance indicators such as the proportion of successfully completed or lost innings, the probability of winning a point depending on various factors, etc. Therefore, it is clear that, from a practical point of view, team coaches are very interested in receiving objective information about quantitative performance metrics that fully take into account the ultimate consequences of performing it.

The study of the problem of determining the efficiency of performing different ways of submission in competitive activities is carried out in this work on the basis of the method [4, 18-20], which was successfully used to solve a similar problem in classical volleyball. It is based on the mathematical processing of relevant statistics related to the submission. We suggest, by analogy with classical volleyball, to keep a record of the code record of their performance in pedagogical observations during competitions. The technique [4] was modified by us, taking into account the specifics of beach volleyball action. In particular, a four-point rating scale ( 1 to 4$)$ is used to analyze relevant statistics and evaluate feed performance. According to the results obtained in [3, 4], a quantitative $\mathrm{Ki}$ indicator is introduced for each estimate. These metrics determine, in essence, the probability of winning a point after the subsequent game activities that accompany the submission. We have selected the following numerical values for $\mathrm{Ki}$ using the results of $[3,4]: \mathrm{K}_{1}=0, \mathrm{~K}_{2}=0.25, \mathrm{~K}_{2}=0.6, \mathrm{~K}_{4}=1.0$. For a detailed definition of these indicators, see work [3, 4].

In this study, in accordance with the results of [2] the quantitative indicator of the efficiency of performing a particular method of serves $(S)$, we will determine the following formula:

$$
S=\sum_{i} n_{i} K_{i} / N
$$

where:

$n_{i}$ - the number of serves that match the index score and the selected scale,
$K_{i}$ - the above values of indexes (index and takes integer values from 0 to 4 ), $N=\sum_{i} n_{i}-$ the total number of completed submissions of this type.

That is, the average efficiency $\mathrm{S}$ determines the combined probability of winning points after completing the innings, which are accompanied by a certain end result of scoring [4].

Because modern beach volleyball usually uses jumping power (more often men), planning and top straight (running from the spot or from the jump), so in our studies, we conditionally split them into two groups: jump and targeted serves, which included the scheduling and top feed $[3,4]$.

We conducted code records of the results of passing the innings during pedagogical observations, which were conducted in the 25 games of competitive activity of the teams mentioned above. The total number of innings in these games was 2055, of which $39.9 \%$ were power innings in the jump and $60.1 \%$ were targeted innings [3]. That is, all the innings that were made by all the players of the teams during the meetings between themselves, which were stipulated in the standings, were taken into account. In the future, when evaluating performance indicators, we will study only the relevant indicators, which are summarized by the results of the analysis of relevant statistics.

A detailed analysis of the statistics regarding the performance of jumping power and targeted serves has been performed. In Fig. In Fig. 1 shows the results of calculations of distributions of fixed filings, which are determined by the ratio of the values of the number of completed filings of this type ni to their total number $\mathrm{N}$, in accordance with the scale of estimates that we used in the performance of this work [3].

Regarding the estimation of the quantitative measure of the efficiency of the submission S, the corresponding calculations using calculated distributions of the number of completed submissions of a certain type with respect to the scale of estimates show that they reach quite high values and are equal to $38.2 \%$ and $40.1 \%$ for power serves in the jump and targeted serves, respectively.

In our view, from the practical point of view of great interest for coaches and team players is the calculated distribution of innings on the conditional areas of the playground and the associated values of the efficiency of the filing in these areas [3]. 


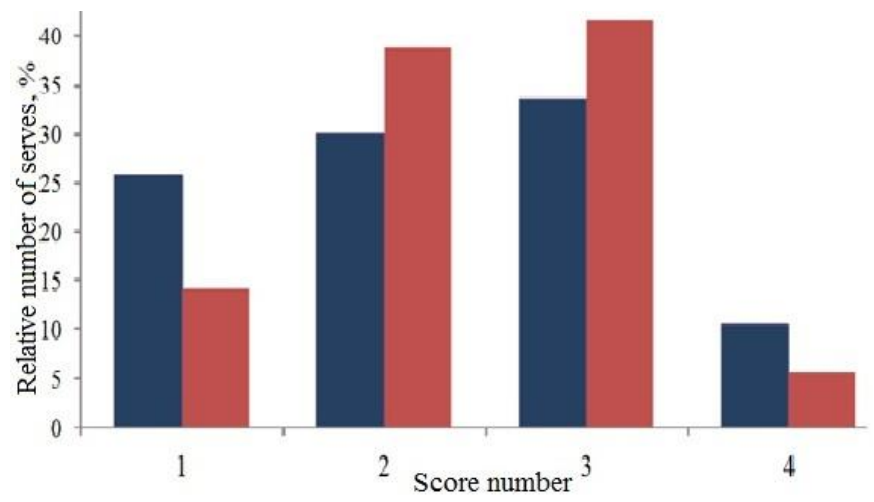

Fig. 1. The distribution of power serves in the jump and targeted serves according to a defined four-point rating scale:

$\square$ - serves in the jump;

$\square$ - targeted serves;

1 - filing out, grid, intersection of the front line;

2 - after receiving the ball, the ball is accurately addressed to the partner (organization of the corresponding attack of the opponent);

3 - after receiving the opponent's submission failed to organize the attack;

4 - loss of a point to a competitor directly after a poor reception of a pass or hit of a ball in his court ("Ace")

In Fig. 2 shows the results of calculating the performance of a jump in power and targeted innings, depending on the number of the playground area, in the direction in which, the corresponding innings, these figures reached the highest values.

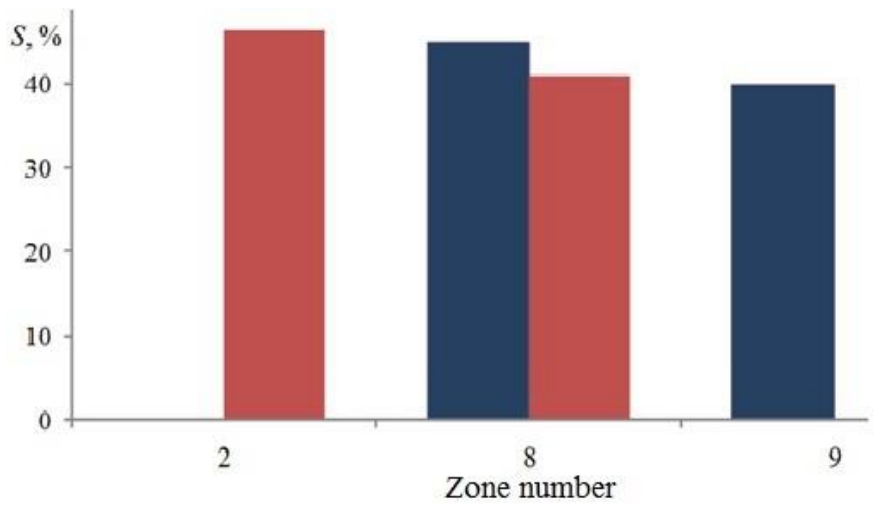

Fig. 2. Performance Indicator of Jumping Power and Targeting Depending on the Playground Area Number:

$\square$ - serves in the jump;

- targeted serves;

S - quantitative indicator of the efficiency of performing a particular method of serves

\section{Discussion}

The results of the study, which are related to the calculations of the power distribution in the jump and the targeted innings according to the determined four-point scale of assessment, show (see Fig. 1) that $25.8 \%$ of the force innings in the jump and $14.1 \%$ of the targeted innings were lost (out or out) relative to the total total innings. The high number of innings lost indicates that many players in the games demonstrated an inability to choose the right way of submission and did not take due account of external environmental conditions [3]. It should be noted that only $10.5 \%$ of power passes in the jump and $5.5 \%$ of targets were won immediately after their execution due to the unsuccessful reception of the opponent's submission or hit of the ball in his court ("aces").

A detailed analysis of the statistics obtained regarding the distribution of completed innings, depending on the number of the playground area to which the players mainly directed them. As the result of this analysis, players tried not to file in the fourth, fifth and sixth zones, because there are opponents, who in most cases accurately addressed the partner's ball to organize the attack. The power supply in the jump was not submitted in zones 1,2 and 3, and the 
largest number was sent to zones 8 and 9 [3]. Moreover, the calculated values of the efficiency of filing in these zones are $45 \%$ and $39.8 \%$, respectively (Fig. 2).

Regarding targeted innings, their focus was mainly concentrated in zone $8-23.5 \%$ of innings, as well as in zone 2 of the playground - 21.3\% [3]. As can be seen from Fig. 2, the performance index $\mathrm{S}$ reached $41 \%$ and $46.3 \%$ for these zones, respectively.

It should be noted that from the tactical point of view 8 the zone is between two players near the front line, which makes it possible to ensure a high probability of winning a point due to the inconsistency of the actions of the opponent's players.

From a practical point of view, it is important for team coaches to have an objective assessment of the quantitative performance indicators of the various modes of submission. In order to further determine the capabilities of the proposed methodology and to verify the validity of the analysis results, it is necessary to carry out the processing of relevant statistical material of a larger volume in order to calculate the performance indicators in the performance of different filing methods as individual players and teams as a whole, depending on the party number and conditional playground areas. Further work is required to perform the appropriate calculations.

\section{Conclusions}

1. A generalized methodology for analyzing statistics on the performance of various methods of submission in beach volleyball competitions and the assessment of appropriate quantitative indicators of their performance. It is based on the results of pedagogical observations of the game, which are combined by a single system of code-recording of the submission of the application using the appropriate four-point rating scale and mathematical processing of the information obtained. When calculating these characteristics, the jump statistics and targeted innings were used to obtain the relevant statistics we obtained from the analysis of 25 Kharkiv beach league games among men's amateur teams.

2. The results of the calculations of the performance of the filing performance show, in particular, that: they reach quite high values and are $38.2 \%$ and $40.1 \%$ for power jump and targeted serves, respectively; the highest values of these indicators were observed in the direction of power serves in the jump zone $8-45 \%$ and targeted serves in zone $2-45,3 \%$.

\section{Conflict of interest}

Authors state no conflict of interest.

\section{References}

1. Gorchanyuk YuA. Improvement of technical training of sportsmen in beach volleyball on the basis of biomechanical models of movements. Fizicheskoe vospitanie studentov, 2008;2:11-17. (in Russian)

2. Kostyukov VV. Beach volleyball (training, technique, tactics). Moscow: Soviet Sport; 2005. (in Russian)

3. Melnik AYu. The technique for the analysis of statistical data concerning execution of different ways of serves in beach volleyball competitions. Naukovopedahohichni problemy fizychnoi kultury. Fizychna kultura $i$ sport. 2019;5(113)19:93-97. (in Ukrainian)

4. Hradusov VO, Lisianskyi VK, Melnyk AYu. The research of efficiency and quality of serves execution by volleyball players of high qualification in the competitive activity. Pedahohika, psykholohiia ta medyko-biolohichni problemy fizychnoho vykhovannia i sportu, 2011;6:26-30. (in Ukrainian)

5. Tilp M, Wagner H, Muller E. Differences in 3D kinematics between volleyball and beach volleyball spike movements. Sports Biomechanics [serial on the Internet]. 2008 [cited 2019 May 27];7(3):386-

397 Available from: https:// www.researchgate.net/. doi.org/10.1080/14763140802233231
6. Beliaev AB, Bulykina LV. Volleyball: theory and technique of training. Moscow: Physical Culture and Sport; 2007. (in Russian)

7. Noël B, Hüttermann S, van der Kamp J, Memmert D. Courting on the beach: how team position implicitly influences decision-making in beach volleyball serves. Journal of Cognitive Psychology [serial on the Internet]. 2016 [cited 2019 June 5];28(7): 868-876 Available from: https://www.researchgate.net/. doi:10.1080/14763140802233231

8. Lin K. Applying game theory to volleyball strategy. International Journal of Performance Analysis in Sport [serial on the Internet]. 2014 [cited 2019 May 23];14(3):761-774 Available from: https:// www.researchgate.net/. doi.org/10.1080/24748668.2014.11868756

9. Medeiros Alexandre IA, Mesquita IM, Marcelino OR, Palao JM. Effects of technique, age and player's role on serve and attack efficacy in high level beach volleyball players. International Journal of Performance Analysis in Sport [serial on the Internet]. 2014 [cited 2019 May 23];14(3):680691 Available from: https:// www.researchgate.net/. doi.org/10.1080/24748668.2014.11868751

10. Giatsis G, Zahariadis P. Statistical Analysis of Men's FIVB Beach Volleyball Team Performance. International Journal of Performance Analysis in 
Sport [serial on the Internet]. 2008 [cited 2019 May 2 0];8(1):31-43. Available from: https:// www.researchgate.net/. doi.org/10.1080/24748668.2008.11868420

11. Giatsis G, Schrapf N, Koraimann T, Tilp M. Analysis of the arm swing technique during the spike attack in elite beach volleyball. International Journal of Performance Analysis in Sport [serial on the Internet]. 2019 [cited 2019 May 23];19(3):370-380 Available from: https:// www.researchgate.net/. doi.org/10.1080/24748668.2019.1611291

12. Michalopoulou M, Papadimitriou K, Lignos N, Taxildaris K, Antoniou P. Computer analysis of the technical and tactical effectiveness in Greek Beach Volleyball. International Journal of Performance Analysis in Sport [serial on the Internet]. 2005 [cited 2019 May 27];5(1):41-

50 Available from: https:// www.researchgate.net/. doi.org/10.1080/24748668.2005.11868314

13. Babushkin GD. The effectiveness of the competitive activity of an athlete and ways to improve it. Sportivnyiy psiholog. 2011;1(32):63-66. (in Russian)

14. Doroshenko EYu, Melnichuk YuV. The analysis of serve efficiency of a ball as an element of technical and tactical activity of qualified volleyball players. Pedahohika, psykholohiia ta medyko-biolohichni problemy fizychnoho vykhovannia i sportu, 2007;6:96100. (in Russian)

15. Nosko MO, Panin AI, Garkusha SV. The management of training and competitive process of volleyball players by means of the system of pedagogical observations. Pedahohika, psykholohiia ta medykobiolohichni problemy fizychnoho vykhovannia i sportu, 2000;13:12-14. (in Ukrainian)

16. Shvai O, Smoliuk V, Solianyk Yu. The comparative analysis of serves at volleyball players of different sports qualification. Fizychne vykhovannia, sport $i$ kultura zdorov'ia u suchasnomu suspilstvi, 2009;3:112-116. (in Ukrainian)

17. Ermakov SS. Computer registration and processing of results of the competitive activity. Theses of the report of the interregional scientific and practical conference, Kharkov 12-16 September 1990. P. 124. (in Russian)

18. Melnik AYu. The research of serve efficiency in volleyball on the basis of technology of Microsoft Access databases. Slobozhanskyi naukovo-sportyvnyi visnyk, 2013;3:185-189. (in Ukrainian)

19. Volkov EP, LIsyanskiy VK. Methodical grant. The management of training and competitive process of volleyball players of high qualification by means of the system of pedagogical observations. Kharkiv: KSAPC; 2002. (in Ukrainian)

20. Melnik AYu. The analysis of efficiency of power jump serves depending on the accuracy of its execution in the competitive activity of volleyball players. Slobozhanskyi naukovo-sportyvnyi visnyk, 2016;5(55):53-56. (in Ukrainian)

\section{Information about the authors}

\section{Melnyk A.Y.}

alina.melnik1987@ukr.net

http://orcid.org/0000-0001-5612-0333

Kharkiv state academy of physical culture

Klochkivska Street 99, Kharkiv, 61058, Ukraine

\section{Strelnykova Y.Y.}

zenastrel@gmail.com

http://orcid.org/0000-0003-0010-6369

H.S. Skovoroda Kharkiv national pedagogical university

Alchevskykh Street 29, Kharkiv, 61002, Ukraine

\section{Інформація про авторів}

\section{Мельник А.Ю.}

alina.melnik1987@ukr.net

http://orcid.org/0000-0001-5612-0333

Харківська державна академія фізичної культури: вул. Клочківська 99, Харків, 61058, Україна.

\section{Стрельникова Є.Я.}

zenastrel@gmail.com

http://orcid.org/0000-0003-0010-6369

Харківський національний педагогічний університет імені Г.С. Сковороди

вул. Алчевських 29, Харків, 61002, Україна 